\title{
ПРОБЛЕМИ ЗАСТОСУВАННЯ АДМІНІСТРАТИВНО-ГОСПОДАРСЬКИХ САНКЦІЙ ЩОДО СУБ'ЄКТІВ НАДАННЯ ОСВІТНІХ ПОСЛУГ
}

Постановка проблеми в загальному вигляді та іiі зв'язок із важливими практичними завданнями. Діяльність закладів вищої освіти, спрямована на забезпечення реалізації права людини на вищу освіту, є системою заходів, які включають організаційні, фінансово-економічні, господарські, освітні, науково-дослідні та інші заходи. 3 огляду на обов'язок держави щодо гарантій на здійснення прав і свобод людини i громадянина, а також важливість цього соціального завдання 3ОВ, забезпечується відповідне правове регулювання суб'єктів освітнього процесу, серед яких інститут юридичної відповідальності, у тому числі пов'язаний із накладенням адміністративних санкцій на порушників освітнього законодавства.

Аналіз останніх досліджень i публікацій. Питання юридичної відповідальності у сфері господарської діяльності, в тому числі в галузі освіти, висвітлювалися в публікаціях таких вчених, як М.П. Баб'юк, І.А. Безуглий, В.К. Грищук, Н.Л. Губерська, Р.В. Гурак, Б.В. Деревянко, І.П. Жигалкін, В.В. Костицький, С.М. Кравченко, С. Кузьменко, О.В. Куцурубова-Шевченко, А.О. Монаєнко, П.В. Нестеренко, Є.А. Огаренко, I.M. Острівний, В.Ю. Поляков, Ю.М. Фролов, Ю.С. Шемшученко та ін.

Формування цілей статті. Основним завданням статті є дослі- дження особливостей застосування адміністративних санкцій щодо суб'єктів освітньої діяльності.

Виклад основного матеріалу. Питання юридичної відповідальності суб'єктів освітнього процесу залишаються важливими поряд із передбаченими освітнім законодавством іншими засобами правового регулювання, в тому числі і такими, як ліцензійно-акредитаційне регулювання. Адміністративно-господарські санкції, застосовувані до ЗВО, окремі загальні заходи адміністративного впливу, мають спеціальний характер. Це стосується, зокрема, такої ключової санкції, як анулювання ліцензії на провадження 3ВО освітньої діяльності у сфері вищої освіти.

Зазначимо, що згідно зі ст. 238 Господарського кодексу України (далі ГКУ) за порушення встановлених законодавчими актами правил здійснення господарської діяльності до суб'єктів господарювання можуть бути застосовані уповноваженими органами державної влади або органами місцевого самоврядування адміністративно-господарські санкції [1]. Під спеціальними адміністративними санкціями в юридичній науці розуміють такий різновид господарсько-правових санкцій, які «безпосередньо спрямовані на охорону правовідносин суб'єкта господарювання, а також органів державної влади і місцевого самоврядування. При застосуванні цих санкцій використовуються владні й адміні- 
стративно-розпорядницькі функції відповідних державних органів, а стягнення 3 порушників здійснюється не на користь їх контрагентів, а до державного або місцевих бюджетів» [2, с. 525]. Зазначені санкції також вважають важливим засобом забезпечення виконання організаційно-господарських зобов'язань та інструментами гарантування прав i законних інтересів суб'єктів господарювання $[3 ; 4 ; 5]$. Їх застосування «має сприйматися не 3 позицій репресивних, а 3 точки зору забезпечення умов й усунення перешкод у формі порушень загальнообов'язкових правил, які стають на шляху якісного розвитку економічних відносин в Україні» [6, с. 90].

Із цих санкцій найсуттєвішими $€$ ліквідація $3 \mathrm{BO}$ як суб'єкта господарювання й анулювання ліцензії на провадження 3ВО освітньої діяльності. 3 огляду на це $є$ сенс окремо дослідити саме анулювання ліцензії як специфічної адміністративно-господарської санкції, застосовуваної до ЗВО.

Під анулюванням ліцензіі законодавець розуміє позбавлення $3 \mathrm{BO}$ як ліцензіата права на провадження виду господарської діяльності, що підлягає ліцензуванню, прийняттям органом ліцензування рішення про анулювання його ліцензіі. Ліцензія вважається анульованою з дня, коли ліцензіат дізнався чи мав дізнатися про анулювання ліцензіі, але у строк, не менший за один тиждень із дня прийняття органом ліцензування рішення про анулювання виданої йому ліцензії (ч. 1 ст. 16 Закону України «Про ліцензування видів господарської діяльності» [7]).

Зазначимо, що анулювання ліцензії вважається припинювальним заходом примусового характеру [8, с. 55-56, 112], а також $є$ складником режиму ліцензування [8, с. 78]. Отже, з огляду на правову природу, це надзвичайно суттєвий захід впливу на $3 \mathrm{BO}$ як на потенційного порушника правил провадження діяльності у сфері вищої освіти. Застосування такого крайнього заходу має відбуватися у виняткових випадках, адже анулювання ліцензії на провадження освітньої діяльності ЗВО суттєво зачепить не лише приватні інтереси осіб, які здобувають вищу освіту у відповідному ЗВО, а й широкі суспільні інтереси, оскільки таке анулювання спроможне безпосередньо позначитися на якості освітнього процесу в ЗВО [9, с. 169-171].

Маємо всі підстави стверджувати, що законодавець не вніс ясності у визначення юридичних підстав для анулювання ліцензії у сфері освітньої діяльності, що суперечить вимогам юридичної визначеності як складника принципу верховенства права. Нагадаємо, що принцип верховенства права, закріплений у Конституції України, не лише визнається, а й діє в Україні (ч. 1 ст. 8 Конституції України [10]).

Зокрема, відповідно до ч. 4 ст. 24 Закону України «Про вищу освіту» [11] підставою для прийняття рішення про анулювання ліцензії ЗВО $€: 1)$ заява 3ВО про анулювання власної ліцензії; 2) наявність у ЄДРПОУ відомостей про державну реєстрацію припинення юридичної особи; 3) акт про невиконання розпорядження про усунення порушень ліцензійних умов провадження освітньої діяльності у сфері вищої освіти; 4) акт про повторне порушення 3 ВО ліцензійних умов (повторним порушенням ЗВО таких умов вважається вчинення протягом двох років із дня видання $\mathrm{MOH}$ України розпорядження про усунення порушень ліцензійних умов нового порушення хоча б однієї 3 вимог ліцензійних умов, щодо якої видавалося таке розпорядження); 5) акт про виявлення недостовірних відомостей у документах, поданих $3 \mathrm{BO}$ разом із заявою про отримання ліцензії; 6) акт про відмову 3ВО у проведенні органом ліцензування перевірки; 7) несплата за видачу ліцензіі; 8) відсутність провадження освітньої діяльності ліцензіатом на певному рівні вищої освіти або за певною освітньою програмою,

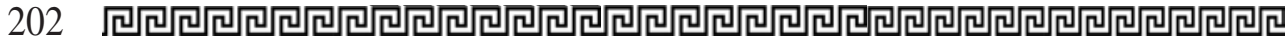


що передбачає присвоєння професійної кваліфікації з професій, для яких запроваджено додаткове регулювання, протягом 365 днів. Акт складається органом ліцензування, підписується його правомочними особами та керівництвом ЗОВ [11].

Рішення про анулювання ліцензії приймається протягом 15 робочих днів із дня виникнення або встановлення підстав для анулювання ліцензії. У разі анулювання ліцензії відповідно до п.п. 1, 3-5, 7, 8 ч. 4 ст. 24 Закону «Про вищу освіту» 3 ВО втрачає право провадити освітню діяльність у сфері вищої освіти за певним рівнем вищої освіти або за певною освітньою програмою, що передбачає присвоєння професійної кваліфікації з професій, для яких запроваджено додаткове регулювання. У разі анулювання ліцензії відповідно до п.п. 2 і 6 цієї частини заклад вищої освіти втрачає право провадити всі види освітньої діяльності у сфері вищої освіти [11].

Мусимо зазначити, що законодавство, яке регулює ці відносини, містить протиріччя, яке порушує принцип системності правового регулювання та системності права [12-14]. Так, зазначені вище правила, встановлені Законом України «Про вищу освіту» щодо двох підстав анулювання ліцензіі у сфері провадження освітньої діяльності 3ВО, не повною мірою кореспондуються із загальними правилами, що містяться в Законі України «Про ліцензування видів господарської діяльності» [15]. У ньому до підстав анулювання ліцензії (окрім волевиявлення самого суб'єкта господарювання) зараховано набагато ширше коло таких обставин: 1) набрання чинності рішенням органу ліцензування про анулювання ліцензії або скасування такого рішення спеціально уповноваженим органом із питань ліцензування; 2) акт про невиконання розпорядження про усунення порушень ліцензійних умов, встановлених для виду господарської діяльності; 3) акт про повторне пору- шення ліцензіатом ліцензійних умов; 4) акт про виявлення недостовірності даних у документах, поданих суб'єктом господарювання разом із заявою про отримання ліцензіi; 5) акт про відмову ліцензіата у проведенні перевірки органом ліцензування; 6) акт про документальне підтвердження встановлення факту контролю (вирішального впливу) за діяльністю ліцензіата осіб інших держав, що здійснюють збройну агресію проти України у значенні, наведеному у ст. 1 Закону України «Про оборону України», та / або дії яких створюють умови для виникнення військового конфлікту, застосування військової сили проти України; 7) несплата за видачу ліцензіі відповідно до ч. 2 ст. 14 Закону (ч. 2 ст. 16 Закону України «Про ліцензування видів господарської діяльності») [15]. 3 урахуванням такої невідповідності, а також того, що обидва законодавчі акти мають рівну юридичну силу в частині підстав анулювання ліцензіі 3ВО, очевидно, підлягають узгодженню, що можна досягти доповненням Закону України «Про вищу освіту» вказівкою на існування й інших, крім уміщених у ньому підстав для анулювання ліцензії 3ВО, зокрема визначених у Законі України «Про ліцензування видів господарської діяльності». Тобто законодавець найперше має взяти до уваги принцип системності права та правило кумулятивного застосування норм обох законів, за відсутності очевидної необхідності дублювання в обох законах ідентичного переліку підстав анулювання ліцензій на провадження освітньої діяльності 3ВО, зокрема для економії нормативного матеріалу.

Звісно, анулювання ліцензіі не означає незворотного та остаточного припинення освітньої діяльності 3ВО, яка може знову розпочатися за умови отримання цим ЗВО нової ліцензії на провадження такої діяльності в порядку, встановленому Законом [11]. Щоправда, як у першому, так і другому випадках законодавець 
не врегулював питання порядку реалізації права на подальше одержання вищої освіти особами, які здобули вищу освіту у ЗВО, позбавленому ліцензії. Це ж стосується і питань врахування оцінювання пройдених навчальних курсів, ї врахування за умови навчання в іншому 3ОВ. Водночас аналогічні правовідносини в разі ліквідації ЗВО законодавець, хоч і не повно, але врегулював, закріпивши право осіб, які здобували освіту в 3ВО, що ліквідований, на гарантоване продовження такої освіти в іншому 3ВО, а також поклавши відповідний обов'язок щодо забезпечення такого права на власника ліквідованого ЗВО. Тому, 3 огляду на коментований вище підхід, необхідно внести кореспондуючі зміни до Закону України «Про вищу освіту» в частині врегулювання в разі анулювання ліцензій ЗВО юридичних наслідків, які передбачали б механізм захисту прав студентів. Перш за все йдеться про надання таким студентам змоги продовжити навчання на тих самих (ідентичних) правових умовах із відповідним рівнем освітніх послуг в іншому 3ВО України. Важливим $€$ питання фінансових умов подальшого навчання студентів в іншому 3ВО в разі позбавлення ліцензії 3ОВ.

На окремий коментар заслуговують інші пропозиції про можливі санкції до ЗВО, що містяться в юридичній літературі. Наприклад, як вирішувати проблеми, якщо діяльність 3ВО набуватиме характеру підприємницької (комерційної) діяльності (з огляду на зміст ст. 42 ГКУ [1]), спрямованої на досягнення результату, який не $€$ соціально значущим, а містить суто фінансово-економічні цілі? Таку ситуацію також необхідно вважати підставою для позбавлення ЗОВ ліцензії [16, с. 239]. Аналізуючи пропозицію в розрізі освітнього законодавства, що зазнало змін, зауважимо, що з огляду на можливість створення ЗВО у формі прибуткового закладу (ч. 1 ст. 27 Закону України «Про вищу освіту» [11]), така пропозиція має сенс лише стосовно 3ВО, створеного в організаційно-правовій формі бюджетної установи або неприбуткового закладу.

За будь-яких обставин, усі підстави анулювання ліцензіі на провадження освітньої діяльності ЗВО варто, очевидно, передбачити саме в Законі України «Про вищу освіту» і не допускати розширювального їх тлумачення, що може призвести до неправомірного звуження обсягу правоздатності ЗВО у сфері господарювання.

Висновки. Проблеми вдосконалення інституту юридичної відповідальності суб'єктів освітнього процесу залишаються важливими поряд із передбаченими освітнім законодавством іншими засобами правового регулювання діяльності 30 . Визначені законом види господарсько-правових санкцій підлягають застосуванню до ЗВО як до суб'єкта господарювання в разі вчинення ним господарського правопорушення, однак правовий механізм регулювання господарсько-правової відповідальності 3ВО не має нині завершеного й комплексного характеру, тому актуальними залишаються дослідження цього інституту та впорядкування законодавства, узгодження норм права, в тому числі на міжгалузевому рівні.

У статті з урахуванням специфіки діяльності закладів вищої освіти (далi - 30В) з використанням аналізу соціальної сутності та призначення вищої освіти проаналізовано підходи до застосування адміністративно-господарських санкцій щзодо ЗОВ. При цььому враховано і проблеми забезпечення права людини на вищу освіту, гарантованого Конституцією України.

Намагаючись уточнити суmь $i$ правову природу конституційного права на вищу освіmy, автор вважає, щз в процесі застосування санкиій щодо ЗОВ мають бути забезпечені права студентів на

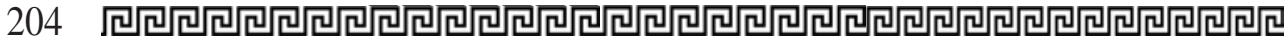


продовження навчання, отримання вищої освіти. Важливим тут $\epsilon$ також врегулювання процедури вирішення иих питань, з’ясування обсягів фінансових розрахунків у разі навчання студентів на платній основі, що сприятиме з'ясуванню співвідношення права на вищу освіту та інших соціальних, економічних та культурних прав.

Доведено чіткий сойіально-правовий взаємозв'язок реалізації права на вищу освіту $i$ формування розгалуженої мережі ЗВО, застосування державою санкиій щодо яких вважається важливим засобом забезпечення виконання організаційно-господарських зобов'язань та інструментами гарантування прав i законних інтересів суб'єктів господарювання, не може сприйматися з позицій репресивних заходів держави, а з точки зору забезпечення умов й усунення перешкод у формі порушень загальнообов'язкових правил, які стають на шляху якісного розвитку соціально-економічних відносин та гарантування права на вищу освіту в Україні.

Означені проблеми розглядаються на фоні аналізу застосування щодо ЗОВ такої санкції, як позбавлення, анулювання ліцензї на освітню діяльність. На підставі дослідження зроблено висновок, що визначені законом види господарсько-правових санкцій підлягають застосуванню до ЗВО як до суб’ $є$ та господарювання в разі вчинення ним господарського правопорушення. Оскільки правовий механізм регулювання господарсько-правової ЗВО відповідальності не має на сьогодні завершеного й комплексного характеру, вносяться пропозиції щодо забезпечення принципу системності правового регулювання освітніх відносин та системності права.

Ключові слова: освіта, вища освіта, конституційне право на освіту, соціальне призначення права на вищу освіту, юридична відповідальність, адміністративно-господарські санкції щодо 3ОВ.

\section{Tymoshenko M. Problems of application of administrative sanctions on the subjects of educational services \\ The article, taking into account} the specifics of the activities of higher education institutions (hereinafter $H E I)$ using the analysis of the social essence and purpose of higher education analyzes the approaches to the application of administrative and economic sanctions on HEI. The problems of ensuring the human right to higher education guaranteed by the Constitution of Ukraine are also taken into account. Trying to clarify the essence and legal nature of the constitutional right to higher education, the author believes that the application of sanctions against HEI should ensure the rights of students to continue their studies, to receive higher education. It is also important to regulate the procedure for resolving these issues, to clarify the amount of financial settlements in the case of tuition fees, which will help clarify the relationship between the right to higher education and other social, economic and cultural rights. A clear socio-legal relationship between the realization of the right to higher education and the formation of an extensive network of free economic zones, the application of state sanctions against which is considered an important means of ensuring organizational and economic obligations and tools to guarantee the rights and legitimate interests of economic entities. to be perceived from the standpoint of repressive measures of the state, and in terms of providing conditions and removing obstacles in the form of violations of mandatory rules, which stand in the way of quality development of socioeconomic relations and guarantee the 
right to higher education in Ukraine. These problems are considered against the background of the analysis of the application of such a sanction as deprivation, revocation of a license for educational activities. Based on the study, it was concluded that the types of economic and legal sanctions specified by law are subject to application to the higher education institutions as a business entity in the event of an economic offense. As the legal mechanism of regulation of economic and legal free economic liability is not completed and complex today, proposals are made to ensure the principle of systematic regulation of educational relations and systematic law.

Key words: education, higher education, constitutional right to education, social purpose of the right to higher education, legal responsibility, administrative and economic sanctions against HEI.

\section{Література}

1. Господарський кодекс України від 16.01.2003 p. Відомості Верховної Ради України. 2003. № 18, 19-20, 21-22. Cm. 144.

2. Богомолова H.M. Відповідальність у сфері господарювання. Правовий вплив на неправомірну поведінку: актуальні грані : монографія / За ред. проф. О.В. Козаченка, проф. Є.Л. Стрельиова. Миколаїв : Iліон, 2016. 525 c.

3. Віхров О. Оперативно-господарські та адміністративно-господарські санкціі як засоби забезпечення виконання організаційно-господарських зобов'язань. Право України. 2009. № 8. С. 99-10.

4. Віхрова I.О. Адміністративно-господарські санкції як заходи господарськоправової відповідальності. Часопис Київського університету права. 2015. № 2. C. 151-155.

5. Войнарівський М.М. Гарантії прав та законних інтересів суб'єктів господарювання при застосуванні адміністративно-господарських санкиій : автореф. дис. ... канд. юрид. наук: 12.00.04. Одеса, 2014. 22 c.

6. Кантор Н.Ю. Адміністративно-господарські санкції як гарантії реалізаціі mа захисту економіннх інтересів держави. Науковий вісник Ужгородського національного університету. 2015. Bun.34, m. 2. C. 90.

7. Про ліцензування видів господарської діяльності : Закон України від 03.03.2015 p. № 222-VIII. Відомості Верховної Ради України. 2015. № 23. Ст. 158.

8. Шапочкіна M.В. Санкцї̈ у структурі адміністративно-правового режиму ліцензування : дис. ... канд. юрид наук : 12.00.07. Ipniнb, 2017. C. 55-56, 112.

9. Кванина В.В. Гражданско-правовое регулирование отношений в сфере высшего профессионального образования : монография. Москва : Готика, 2005. C. 169-171.

10. Конституція України від 28.06 .1996 р. Відомості Верховної Ради України. 1996. № 30. Ст. 141.

11. Про вищу освіту : Закон України від 01.07.2014 р. Відомості Верховної Ради України. 2014. № 37-38. Cm. 2004.

12. Костицький В.В. Норма права як соціальний феномен: теолого-соціологічне праворозуміння. Соціологія права. 2015. № 3-4 (14-15). С. 3-6.

13. Костищький В.В. Десять тез про юридичну відповідальність за екологічні правопорушення. Про українське право. Yасопис кафедри теоріï ma iсторіï держави $і$ права Київ. Нац. ун-ту імені Тараса Шевченка / За заг. ред. проф. I. Безклубого. 2010. Чис. V. C. 312-322.

14. Костищький В.В. До питання про розвиток системи права та критеріі його поділу на галузі (на прикладі екологічного й повітряного права). Про українське право: Часопис кафедри теорії та історії держави і права Київ. наи. ун-ту імені Тараса Шевченка / За ред. проф. I. Безклубого. 2009. Чис. IV. C. 128-143.

15. Про ліщензування господарської діяльності: Закон України від 03.03.2015 p. № 222-VIII. Відомості Верховної Ради України. 2015. № 23. Сm. 158.

16. Гурак Р.В. Особливості господарсько-правової відповідальності державних вищих навчальних закладів. Проблеми законності. 2011. Buп. 114. С. 239. 